(C) Ковальская Светлана Ивановна - доктор исторических наук, профессор кафедры истории Казахстана, Евразийский национальный университет им. Л.Н. Гумилева, 010008, Казахстан, Астана, ул. Сатпаева, 2. E-mail: skovalsk@mail.ru. ORCID: http://orcid/org 0000-0001-7613-7597

(c) Любичанковский Сергей Валентинович - доктор исторических наук, профессор, заведующий кафедрой истории России, Оренбургский государственный педагогический университет, 460014, Российская Федерация, г. Оренбург, ул. Советская, 19.

E-mail: svlubich@yandex.ru. ORCID: http://orcid.org/0000-0001-8349-1359

\begin{abstract}
АННОТАЦИЯ
В статье, во-первых, анализируется, каким образом система образования становится одним из основных каналов модернизационных и аккультурационных преобразований, как образование влияет на процесс эмансипации человека, формирование интеллигенции, пробуждение национального самосознания и появление в общественно-политической мысли различных, в том числе радикальных, политических учений, некоторые из которых непосредственно привели к смене политической власти государства. И во-вторых, исследуется данная проблема с активным привлечением трудов казахстанских, российских и зарубежных англоязычных авторов по вопросу внедрения системы образования среди нерусских народов Российской империи и затем СССР.

Основным методом исследования является историографический анализ трудов ведущих специалистов в изучаемой области. Метод компаративистики применялся при анализе подходов, существующих в историографии по изучаемой теме. Кроме того, активно использовались методы ретроспективного и перспективного анализа.

Среди источников изучения - различные по типологии документы: как государственные законодательные акты различного уровня, так и отдельные труды представителей казахской интеллигенции. Кроме того, к анализу были привлечены труды западных ученых, разрабатывающих данную проблематику в сравнительно-сопоставительном аспекте.

Основной вывод сводится к утверждению, что образование, открывая перспективы развития, максимально способствует эмансипации человека, становится основным средством его освобождения и борьбы за политические цели, активно стимулируя процессы формирования национального самосознания и нациестроительства.
\end{abstract}

Ключевые слова: аккультурация, модернизация, империя, колония, казахи-кочевники, историография, система образования.

Цитирование. Ковальская С.И., Любичанковский С.В. Российская образовательная система как канал аккультурации и модернизации сознания казахов-кочевников XVII - начала XX веков // Вестник Самарского университета. История, педагогика, филология. 2018. Т. 24. № 2. С. 7-15. DOI: https://doi.org/10.18287/2542-0445-2018-24-2-7-15.

Благодарности. Исследование выполнено за счет гранта Российского научного фонда (проект №17-18-01008), реализуемого в Оренбургском государственном педагогическом университете.

This is an open access article distributed under the Creative Commons Attribution License Which permits unrestricted use, distribution, and reproduction in any medium, provided the original work is properly cited. (CC BY 4.0) 


\title{
RUSSIAN EDUCATIONAL SYSTEM AS A CHANNEL FOR ACCULTURATION AND MODERNIZATION OF CONSCIOUSNESS OF NOMADIC KAZAKHS OF THE XVIII AND BEGINNING OF THE XX CENTURIES
}

\author{
(C) Kovalskaya Svetlana Ivanovna - Doctor of Historical Sciences, professor of the Department of History \\ of Kazakhstan, L.N. Gumilyov Eurasian National University, 2, Satpaeva Street, Astana, 010008, Kazakhstan. \\ E-mail: skovalsk@mail.ru. ORCID: http://orcid/org 0000-0001-7613-7597 \\ (C) Lyubichankovsky Sergei Valentinovich - Doctor of Historical Sciences, Professor of the Department of the \\ History of Russia, Orenburg State Pedagogical University, 19, Sovetskaya Street, Orenburg, 460014, Russian \\ Federation. \\ E-mail: svlubich@yandex.ru. ORCID: http://orcid.org/0000-0001-8349-1359
}

\begin{abstract}
In this article, we will try, first of all, to understand how the education system becomes one of the main channels of modernization and acculturation reforms. How does education affect the process of emancipation of a person, the formation of the intelligentsia, the awakening of national identity and the emergence of various, including radical political doctrines in social and political thought, some of which directly led to a change in the political power of state. Secondly, we will try to analyze this problem by actively involving the works of Kazakhstani, Russians and foreign English-speaking researchers on the introduction of the education system among non-Russian peoples of the Russian Empire and then the USSR.

In this article, we will try to analyze the process of penetration of the idea of education into the Kazakh society, as well as the formation of Russian and then Soviet educational policy towards the Kazakhs. As a result, a critical mass of representatives of the Kazakh intelligentsia was formed, all thoughts and aspirations of which began to revolve around the idea of their own national development and the realization of an independent national project, which became possible on the wave of Russian revolutions of the early $20^{\text {th }}$ century.

The main method of research is a historiographic analysis of the works of leading specialists in the field under study. The method of comparative studies became the main one in analyzing the approaches that exist in historiography. In addition, methods of retrospective and prospective analysis were actively used too.

Sources of study were various types of documents. Among them, there are state legislative acts of various levels, as well as individual works of representatives of the Kazakh intelligentsia. In addition, the analysis involved the works of Western scholars who develop this problem in a comparatively aspect.

The main conclusion boils down to the assertion that education, opening the prospects for development, maximally contributes to the emancipation of man, becomes the main means of its liberation and struggle for political purposes, actively stimulating the processes of formation of national self-consciousness and nation building.

Key words: acculturation, modernization, Empire, colony, nomadic Kazakhs, historiography, education system.

Цитирование. Kovalskaya S.I., Lyubichankovsky S.V. Rossiyskaya obrazovatel'naya sistema kak kanal akkul'turatsii i modernizatsii soznaniya kazakhov-kochevnikov XVII - nachala XX vekov [Russian educational system as a channel for acculturation and modernization of consciousness of nomadic Kazakhs of the XVIII and beginning of the XX centuries]. Vestnik Samarskogo universiteta. Istoriia, pedagogika, filologiia [Vestnik of Samara University. History, pedagogics, philology], 2018, Vol. 24, no. 2, pp. 7-15. DOI: https://doi.org/ $10.18287 / 2542-0445-2018-24-2-7-15$.
\end{abstract}

Acknowledgements. The research is executed at the expense of a grant of the Russian Science Foundation (project No. 17-18-01008) in the Orenburg State Pedagogical University. 
Отношение к образованию со стороны царского правительства в дореволюционный период носило двойственный характер. С одной стороны, Российская империя остро нуждалась в укреплении своей технико-экономической и военной мощи, с другой чем образованнее и свободнее становились граждане, тем серьезней была угроза прочности самодержавия. Нерусские народы Российской империи традиционно воспринимались как потенциальная угроза дезинтеграции страны.

Модернизация, безусловно, дает толчок развитию национальных социальных и интеллектуальных элит, которые встают на путь собственного национального строительства. Образование постепенно становится одним из основных каналов модернизационных и аккультурационных преобразований среди казахов-кочевников. Со второй половины XVIII Российская империя постепенно начинает открывать различные учебные заведения в казахской степи. В 1789 году в Омске открывается Азиатская школа, позже - Кадетский корпус.

Издавая «Устав о сибирских киргизах» 1822 года, где записано, что каждый казах может поместить сына в учебное заведение империи на общих основаниях, или держа курс в реформах 1860-1890-х годов на развитие аульных школ, империя не могла, да и не собиралась охватить все население. Только примерно $10 \%$ детей могли получить начальное образование в крае. Многими казахами учеба в русских школах расценивалась как принятие христианской веры и вызывала отчуждение и непонимание. В то же время молодежь, не имея аттестата об окончании гимназии, не могла поступить в университет и т. Д.

Как бы то ни было, с 1868 года начальные школы должны были открываться в каждом селении. Благодаря усилиям джадидов постепенно организуется новометодное обучение на тюрко-татарском языке. В Казахстан приезжают и работают ученые с мировыми именами - В.В. Радлов, П.П. СеменовТян-Шанский, М.И. Венюков, И.В. Мушкетов и др. В 1868 году в Оренбурге был открыт филиал Императорского русского географического общества, с 1877-го его филиал открыт в Омске. К 1917 году в Казахстане насчитывается 146 публичных библиотек. Открываются краеведческие музеи. В крупные города приезжают театральные труппы, а с 1858 года в Оренбурге функционирует постоянный театр.

Элита, как правило, «облучалась» инновациями, в первую очередь через образование, гораздо быстрее, нежели народ, хотя могла и не принимать таковые, зачастую возглавляя народно-освободительные движения в крае, как, например, семья Касымовых. В результате такого проявления неповиновения властям российская администрация отказалась от ставки только на традиционную белокостную знать и буквально открыла дорогу для карьеры всем домогающимся власти под эгидой империи. Принятие уставов 1822 и 1824 годов только ускорило этот процесс. Главным теперь было не происхождение, а верность и служение импе- рии. Кстати, именно частое неповиновение властям, даже, казалось бы, особых приверженцев таковой, привело к эволюции института присяги в казахской степи. В «Уставе о сибирских киргизах» в разделе «Сравнение в чинах» было буквально записано следующее: «Старший султан имеет быть везде признаваем и почитаем в чине майора российской службы, пока пребывает в должности. Даже и после срочной смены старший султан считается в числе почетнейших султанов и, ежели прослужит три срока, имеет право просить диплом на достоинство дворянина Российской империи; чин же удерживает тот, который ему действительно пожалован будет: Султаны, управляющие волостями, имеют значение чиновников 12 класса. Старшины и бии, ежели не имеют действительных чинов, считаются наравне с сельскими головами» [Левшин, с. 403].

Модернизация обычно имеет избирательный характер. Чаще всего заимствуются технические или военно-промышленные инновации, наблюдается рост централизации и бюрократизации управления. Как правило, модернизация направлена сверху вниз, обратный импульс чаще всего отсутствует. Потеря традиций приводит к проявлению социального недовольства, которое может выразиться в социальном взрыве и к откату от инноваций, т. е. привести к возрождению идеалов прошлой жизни.

На примере Казахстана можно сказать, что все негативные последствия модернизации проявились в полной мере, так как модернизация практически на каждом из этапов являлась догоняющей, что привело к колоссальной маргинализации, люмпенизации большей части населения, которая накопила невиданный по своей силе заряд ненависти ко всему, что было для них чужой культурой и чужим миром. Кроме того, государство, государственные институты, безраздельно доминируя, оказывали угнетающее воздействие на общественное сознание, формирование национальной культуры и национального самосознания.

Процесс присоединения Казахстана к России вызвал к жизни два течения в общественно-политической мысли Казахстана: пророссийское и антироссийское. Иначе их можно обозначить как просветители и традиционалисты или консерваторы, представленные поэтами эпохи «Зар-Заман» (в первую очередь Шортамбаем Канаевым и Дулатом Бабатаевым), - почти как западники и почвенники в российской традиции, хотя такое строгое разделение не совсем верно. В начале XX века проявятся еще два течения в общественно-политической мысли Казахстана: либерально-демократическое и социалистическое.

Беспощадная критика всего, что характерно для современной им казахской жизни, составляет главную особенность творчества Шортамбая Канаева и Дулата Бабатаева. Поэты эпохи «Зар-Заман» оглядывают всю казахскую действительность и не находят в ней ничего, что могло бы порадовать сердце. Безнравственность, сплетни, косноязычие, презрение к страданиям ближнего, глупость, невеже- 
ство заполнили мир казаха, кажется, что даже скот стал непослушным и строптивым. К критике аульной действительности прибавляется ненависть ко всему чужому, неказахскому, проникающему в степь вместе с колонизацией Казахстана. Авторы впадают в глубокое уныние, нигде не найдя себе утешения. Только прошлое казалось им идеальным, только религия была спасением.

Ценностной подоплекой почвенничества является утверждение самоценности, самодостаточности своей культуры, протест против оценки ее как второсортной, бледной копии других культур. Выдвижение почвеннической идеи в науке связано с определенными процессами массового сознания: актуализацией национальной идеи, ростом национального самосознания, популярностью лозунгов национального возрождения.

Казахское почвенничество несвободно от типических примет этого направления: идеи самобытности национального характера, неповторимости и самоценности казахской культуры, особой преобразовательной миссии кочевой цивилизации в мировой культуре как посредника между Востоком и Западом, национального самоутверждения и саморазвенчания.

Консерваторы были сторонниками сохранения опыта предшествующих поколений в каждодневной практике и привели к формированию консервативной формы политической практики, выраженной в тактике постепенного ухода от действительности через усиление собственной религиозности. Религиозное (исламское) совершенствование личности - вот их основная идея.

М.Б. Олкотт пишет: «В дореволюционный период в казахском обществе существовало четкое разделение между сторонниками светского и религиозного направления модернизации. Первые выступали за адаптацию общества к изменившимся условиям, в то время как вторые ратовали за сохранение традиционных нравов в социальных отношениях и культуре» [Olcott, 1985, p. 189]. На наш взгляд, такое четкое разделение вряд ли присутствовало, так как всегда наличествовала религиозная составляющая. Другое дело, насколько она себя позиционировала.

Немало споров идет вокруг проблемы специфики казахского просвещения. Обычно его появление связывается с реакцией на известное отставание кочевого казахского общества от культурного уровня России. Отсюда вытекает вывод, что просветительство - привнесенный элемент в духовную жизнь кочевников и не имеет глубоких корней в их собственной культуре. Безусловно, такая трактовка не может удовлетворить современного читателя. Кризис кочевого общества явился переломным моментом в духовной сфере кочевья. Расслоение кочевого общества все чаще заставляло вглядываться и анализировать то, что происходило вокруг, а главное - надо было дать ответ на вопрос, что же делать дальше. Род, племя, племенной союз перестают быть относительно однородной массой - эти новые для степной поэзии мо- тивы начинают появляться в творчестве целого ряда поэтов, первым из которых был Актамберды Сарыулы. Критическим духом наполнены произведения Ч.Ч. Валиханова, Абая Кунанбаева, Ибрая Алтынсарина, Мухаметжана Сералина, Султанмахмута Торайгырова и многих других. Однако, в отличие от поэтов эпохи «Зар-Заман», для представителей просветительства были характерны иные настроения - движение вперед возможно и необходимо. Для них образование становится главной ценностью, а получить образование и доступ к мировым ценностям тогда можно было только через русский язык и русскую культуру.

Можно утверждать, что в Российской империи сосуществовали три образовательные концепции. Первая получила оформление в Правилах 1870 года, где была четко выражена цель образования инородцев - русификация и слияние с русским народом. Все инородческие народы делились на несколько групп. В отношении тех, кто понимал русский язык (украинцы и белорусы), действовал запрет на использование родного языка в процессе обучения. Иврит и идиш могли применяться только для обучения в еврейских конфессиональных школах хедерах, йешивах. Мусульманские народы должны были первоначально обучаться на родном языке с последующим переводом на русский язык обучения. Был еще один путь - обучение могло сразу идти на русском языке, но учитель должен был знать родной язык обучающихся детей [Kreindler, p. 204-205].

В целом по данному направлению сегодня издано немало работ, посвященных различным народам Российской империи, среди которых можно назвать статьи С.В. Джунджузова, В.В. Дмитриева и С.В. Любичанковского [Джунджузов, Любичанковский, 2017 a, 2017 б; Дмитриев, Любичанковский; Любичанковский, 2017].

Становлению системы российского образования среди казахского населения посвящен ряд работ современных ученых Казахстана. Среди них можно назвать диссертационные исследования Н.А. Адельбаевой, А.А. Айтмухамбетова, статьи Р.С. Буктугуровой и ряда других [Адельбаева; Айтмухамбетов; Буктугурова].

Автором второй из образовательных концепций был Николай Иванович Ильминский (1822-1892) тюрколог, арабист, профессор турецко-татарского языка в Казанском университете, делом всей жизни которого была христианизация народов Поволжья, Урала и Сибири. Н.И. Ильминский боролся всеми возможными путями против исламизации степи, подчеркивая, что казахи должны иметь собственное направление в развитии. Путь этот он видел через просвещение, народную школу на родном языке, где учителем будет сам инородец. Ильминский стремился через родной язык приобщить инородцев к православию. Христианизация у него шла впереди русификации. Переехав в 1858 году в Оренбург, Николай Иванович выучил казахский язык и вел деловую переписку на казахском языке. Он один из первых на основе русской графики 
создал казахский алфавит, был автором «Самоучителя русской грамоты для киргизов» (1861). В 1879 году Ибрай Алтынсарин, чье становление как просветителя и педагога во многом было определено личностью Ильминского, издал «Киргизскую хрестоматию». Необходимо упомянуть тот факт, что еще в XVIII веке генерал-майор Скалон создал азбуку-букварь казахского языка на основе русской графики.

Интересны в этом плане тезисы Ч. Хостлера, который характеризует позицию Н.И. Ильминского как противника образования тюрко-татарского населения империи по-европейски, так как для тюрков есть опасность принятия православия, а для русского общества существует более серьезная опасность: националы напишут роман на своем родном языке [Хостлер, с. 166]. А значит, разовьют собственное интеллектуальное поле до такого уровня, что оно будет максимально способствовать росту национального самосознания и пробудит стремление к самостоятельному развитию, что опасно с точки зрения государства.

Важно добавить, что на сегодняшний день позиция Н.И. Ильминского как автора первых аккультурационных моделей для инородческого населения активно пересматривается, так как все более детально изучается вклад оренбургской администрации, а именно В.Н. Татищева и Л.Я. Соймонова, в приобщение башкир к русской культуре. Так, последние уже в 1738 году стояли у истоков Уфимской школы, которая была открыта для обучения «инородцев» русскому языку и «познания закона христианского и законов гражданских» [Очерки..., с. 287].

Часть казахской интеллигенции XIX века, пытаясь найти выход из кризиса, в который все больше погружался кочевой социум, ратовала за усвоение русского языка как инструмента, облегчающего доступ к достижениям мировой цивилизации, а также политического воздействия на российские власти и конструирования собственного самостоятельного будущего. Безусловно, эти идеи были характерны для всей мусульманской интеллигенции Российской империи, особенно ее джадидской части, вдохновленной идеями Исмаила бей Гаспринского (Гаспиралы). В Центрально-Азиатском регионе в этот период также наблюдались начала модернистских («джадидских») исканий среди тонкой прослойки местного духовенства, педагогов, поэтов.

Показателен пример Абая, который мы не можем обойти своим вниманием. В двадцать пятом слове «Книги слов», размышляя о том, какое образование необходимо дать казахским детям, мыслитель приходит к однозначному выводу: «Нужно учиться русской грамоте» [Абай, с. 39]. Абай предлагал казахскую самость удерживать при помощи ислама, а цивилизовываться посредством русского языка и культуры.

Приобщение к русскому языку и российской цивилизации - это был «перевод с перевода», так как русская культура к этому времени во многом являла собой также «перевод», но уже цивилиза- ции Запада. И этот «перевод» дался не без труда, не без утраты русскости. Когда русское самодержавие вовлекало общественность в модернизированный европейский мир, оно и отдаленно не могло предвидеть, какую опасность для государственного строя в итоге это в себе таит. Абай также пока не предчувствует будущих утрат для «казахскости». Взгляд его в будущее оптимистичен, он критикует недостатки казахского кочевого общества, призывает сдвинуться с мертвой точки, преодолеть инерцию и развиваться.

По мнению И. Крейндлер, особенно успешно система Н.И. Ильминского была применена в отношении так называемых бесписьменных народов, особенно среди тех, у кого были сильны языческие традиции. «Впервые эти народы получали основные современные средства культуры, и у них появлялась национальная интеллигенция, способная пользоваться этими средствами», - отмечала Изабелла Крейндлер [Kreindler, p. 202]. Народы, которые имели письменность и богатое культурное наследие, в меньшей степени подпадали под влияние системы Н.И. Ильминского. Однако в ряде случаев именно распространение русского языка стимулировало реформаторские настроения среди национальной интеллигенции. Яркий тому пример Исмаил бей Гаспринский и его последователи.

Г. Липсет отмечал, что, так как в Туркестане не было «такого культурного вакуума», как у «степных народов», привлечь детей в русские школы было чрезвычайно сложно. В них учились дети знати, другие же предпочитали русским школам традиционные мектебы и медресе. В 1889 году в гимназиях среди учащихся дети из мусульманских семей составляли всего 1,8 \% [Lipset, p. 317]. Марта Брилл Олкотт, изучая данную проблему, подчеркивает наличие тайных мусульманских школ в условиях постепенно выстраивающихся преград для распространения ислама со стороны российского правительства. При этом автор подчеркивает присутствие сложной дилеммы, перед которой оказалась казахская интеллигенция: опираться на ислам как на часть культурного наследия или отвергнуть его ради модернизации и европеизации казахов. На ее взгляд, окончательное решение этой проблемы смогла предложить только революция [Olcott, 1995, p. 101-112].

Значительное внимание в зарубежной историографии традиционно уделялось анализу влияния дореволюционных общественно-политических движений и российских революций на процесс формирования интеллигенции. Это особенно важно отметить, так как «корни революции» западные авторы, как правило, стремились найти в своеобразии русской общественно-политической мысли, утверждая, что революционный путь России был вымощен «брожением интеллигенции». Так, по мнению английского ученого Г. Сетон-Уотсона, Россия была в числе первых стран, поставивших одну из острейших проблем «неразвитых обществ»проблему революционной интеллигенции [SetonWatson, p. 9]. Кроме того, зарубежные авторы пре- 
имущественно рассматривают вопросы, связанные с давлением тоталитарного государства как на непосредственно саму интеллигенцию, так и на общественно-политическую и социально-культурную жизнь советского общества. В целом проблема взаимоотношений государства и интеллигенции была емко сформулирована М. Малиа: «Современное общество не в состоянии обойтись без интеллигенции, но может ли оно жить вместе с нею?» [Malia, 1972, p. 204]. И действительно, если признать за интеллигенцией право профессиональной ориентации на познание внутренней сущности явлений и процессов, то определяющими характеристиками для нее будут скептицизм, критичность, аналитическое отношение к возникающим проблемам. Все это в совокупности порождает возникновение различных радикальных теорий и даже может привести к смене политического режима в стране, что в итоге и произошло в Российской империи.

K 80-м годам XX столетия в зарубежной историографии стало лидировать направление, суть которого сводилась к попытке представить любую революцию как один из возможных этапов процесса модернизации независимо от уровня развития той или иной страны. Подобный подход позволял характеризовать революцию как насильственный метод решения тех проблем, которые могли бы быть решены с наименьшими потерями в ходе постепенных преобразований. П. Дьюкс, в частности, отмечал, что «отсутствие насилия даже в условиях мирной модернизации всегда было лишь весьма относительным» [Dukes, p. 50, 75]. Достаточно часто в западной литературе можно было встретить предостережение от возможных последствий революционных преобразований. «Русский трагический эксперимент свидетельствует, как важно, чтобы мудрость и государственный подход возобладали над насилием в сложном и деликатном процессе модернизации», - писал американский исследователь А. Адамс [Adams, p. XIV].

По мнению М. Малиа, политические институты России в меньшей степени, чем где бы то ни было, «фильтровали» внутренне присущие интеллигенции профессиональные свойства, делая тем самым «невозможным приспособление ее стремлений в их непосредственной политической форме» к существовавшему общественному строю. Отсюда он делает вывод, что в русской интеллигенции сильнее, чем в интеллигенции какой-либо другой страны, проявлялось негативное отношение к общепринятым ценностям, традициям и институтам [Malia, 1972, p. 207; Malia, 1976, p. 173].

М. Конфино характеризовал интеллигенцию как глубоко вовлеченную в решение национальных проблем и активно выступающую против «старых традиций». К последним автор относил образование, быт и стиль поведения. Стремление к новым традициям рассматривается им как стремление европеизированной интеллигенции к интеллектуальной свободе, которое отнюдь не вело к критике существовавших социальных институтов и было вызвано попытками правительства установить стро- гий контроль над «импортированными идеями» [Confino, p. 119-121].

Попытку выявить «исторические силы» и «институционные характеристики» процесса формирования радикального движения в Российской империи были предприняты Д. Броуэром в его работе «Воспитание нигилистов. Система образования и радикализм в царской России». По его мнению, основанная по образцу прусской и австрийской моделей система российского образования создавала искусственные трудности для обучающихся. Знания давались ценой огромных усилий и «механического запоминания», что и становилось источником оппозиционных настроений молодежи. Ситуация усугублялась стараниями иностранных учителей, которые внушали своим воспитанникам презрение к родному языку и неуважение к русским национальным обычаям [Brouer, p. 23, 35, $36,127]$. К указанным характеристикам он причислял также усилия со стороны государства, направленные на формирование чувства гражданственности, особого понимания чести, элитности и равенства, что в конечном итоге и сформировало особое «отношение к жизни» у той части общества, которую мы называем интеллигенцией [Brouer, p. 121-122, 127-128].

Неоднозначная оценка казахскими мыслителями рубежа веков XX-XXI веков интеллектуального и духовного влияния России вызвана, с одной стороны, желанием глубже осмыслить свои социальные проблемы, с другой - стремлением определить собственное место относительного чужого источника своей культуры. Колоссальное богатство русской культуры вызывает двоякое чувство: притяжение и одновременно отталкивание и даже отторжение.

Последнее, как правило, проявлялось в политическом и социальном национализме, суть природы которого состоит в своего рода защитной реакции вестернизированных представителей казахской интеллигенции при встрече с русско-европейской культурой. Отрыв от традиционной культуры привнес в их состояние определенную раскрепощенность, активность, социальный оптимизм. Образование само по себе становится «фактором освобождения», поскольку расширяет кругозор и возможности человека.

«Национальной матрицей» называл систему образования Николас Ханс. Он писал: «Переход от Российской империи к интернациональному Советскому Союзу не более чем смена названия, но не сущности», тем самым подчеркивая, что характер советской школы определялся не столько политикой партии, сколько русскими образовательными традициями [Hans]. Истоки этих традиций он обнаруживал в географических и климатических условиях, исторических судьбах нации, родном языке, религиозных и культурных особенностях.

Достаточно оригинальным выглядит предпринятое Исааком Кэндлом сравнение советской образовательной политики с той системой, которая функционировала еще при царском режиме. 
Он сопоставляет уваровскую триаду, суммировавшую иррациональные ценности, следующим образом: религиозное православие соответствует «православию экономическому», вместо самодержавия установлено «партийное самодержавие», народность превратилась в классовое сознание. По его мнению, видоизмененная триада есть не что иное, как «манифестация русской нации» [Kandel].

Такой подход к анализу образовательной ситуации был весьма популярен вплоть до 80-х годов. Уильям Джонсон, развивая данный тезис, отмечал следующее: система высшего образования, как и прежде, обслуживает лишь элиту - только теперь это «советская знать», главным критерием приема в вузы остается родовитость - прежде аристократическая, теперь партийная [Johnson]. При этом автор согласен с тем, что определенные новации возможны, но генеральное направление развития образования остается, на его взгляд, прежним.

Безусловно, здесь есть над чем подумать и поспорить. Далеко не так однозначно можно рассматривать ситуацию в образовательной сфере СССР. Впрочем, само существование Советского Союза представляет собой удивительное смешение парадоксальных, несовпадающих, во многом противоречащих друг другу процессов и явлений. В частности, положение интеллигенции в советской системе характеризуется рядом специфических черт, а объективно прогрессивная роль СССР на мировой арене определила неоднозначное отношение к системе со стороны мировой общественности. Советское государство весьма нуждалось в работниках интеллектуальной сферы, т. к. было чрезвычайно идеологизировано, стремилось достичь первенства во всех областях, отводя при этом огромную роль образованию, науке и воспитанию. Большевики, советы, партия нуждались лишь в представителях интеллигенции, а не в интеллигенции, осознающей себя как некое целое [Гуревич, с. 27-28].

Большинство западных специалистов по СССР были склонны видеть в системе образования основной источник советского могущества. Прорыв в этой сфере, произошедший в СССР, практически не с чем сравнить. Страна, которая в сравнении с западными государствами еще в начале XX века оставалась на уровне рубежа XVIII-XIX вв., к концу 50-х годов XX века не просто опережала ведущие мировые державы по целому ряду показателей в области образования, но и бросала ему открытый вызов. Нейджел Грант писал, что СССР можно понять через школу, которая в концентрированном виде выражает «вчерашние традиции, сегодняшнюю политику» и формирует «завтрашних граждан» [Grant].

Мы видим, что большинство западных авторов создавали свои труды в соответствии с теорией тоталитаризма и концепцией преемственности в российско-советской образовательной политике. Безусловно, были и другие мнения, иногда диаметрально противоположные, чему в немалой степени способствовало формирование ревизионистского направления в зарубежной историографии. С осо- бой остротой проблема преемственности в образовательно-педагогических традициях обсуждалась на Западе после «спутникового шока», а затем после распада СССР. Выход за рамки нации привел первоначально часть исследователей к утверждению приоритета универсализма, затем глобализации, а теперь виртуализации.

По проблемам формирования системы образования среди тюркских мусульманских народов СССР в западной науке создано достаточно много интересных трудов. Принадлежат они перу различных авторов, но наиболее плодотворно работали над этой проблемой Каррер д’ Анкосс, И. Крейндлер, Г. Липсет, У. Медлин. Из современных авторов необходимо отметить Р. Уортмана [Wortman, 2011]. Бросается в глаза тот факт, что перечисленные авторы, как правило, опираются на русскоязычные источники. Действительно, многие исследователи старшего поколения не знали языков тюркских народов, да и контакты с национальной интеллигенцией в советское время были весьма ограничены, чего не скажешь о дне сегодняшнем. Новые поколения зарубежных исследователей активно изучают языки Центральной Азии, часто и подолгу работают в центральноазиатских государствах благодаря различным образовательным фондам и выделяемым грантам. Все в совокупности способствует более глубокому постижению реалий не только дня сегодняшнего, но и времен не так давно ушедших.

Представители казахского просвещения, предлагая собственную эволюционную модель дальнейшего развития кочевого социума, допускали только поступательное, соответствующее народным традициям развитие. Внешние воздействия касались в основном изучения русского языка, который был для них прежде всего средством выхода на новый уровень развития, инструментом, который поможет интегрироваться в общемировое пространство. Правда, полное осознание глубины этих процессов пришло далеко не сразу.

Особенность собственно казахской консервативной мысли заключалась в том, что она являлась одновременно и реакцией на происходящие модернизационные процессы, и ее прямым следствием, поскольку все теоретические основы заимствовались чаще из книг российских, реже - европейских мыслителей, идеи которых обычно постигали в русском переводе. Необходимо подчеркнуть, что любые теоретические построения казахской интеллигенции начала XX века были связаны с проблемой обретения политических свобод и процесса нациестроительства. Создание собственной государственности, возвращение самоуважения будущим гражданам, интеллектуальное совершенствование общества, развитие его скрытых потенций в поиске новых жизненных стратегий взамен кочевых вот основные проблемы, которые обсуждались национальной интеллигенцией. И, что самое главное, апелляция к прошлому, лучшим поведенческим образцам настоящих патриотов Казахского ханства была в основе всех подобных рассуждений. 
Внедрение российской системы образования, ее аккультурационный и модернизационный эффект был прямо противоположен первоначальной цели обучить, воспитать и подготовить преданных Российскому государству чиновников из числа казахов-кочевников. Российское образование, которое все активнее внедрялось в кочевую казахскую среду, безусловно, подготовило определенное число государственных служащих, в том числе и преданных империи, но в целом привело к тому, что сформировалась критическая масса представителей казахской интеллигенции, все мысли и чаяния которых стали вращаться вокруг идеи собственного национального развития и реализации самостоятельного национального проекта, что стало возможным на волне русских революций начала XX века. Таким образом, можно констатировать, что образование, являясь одним из аккультурационных и модернизационных каналов, становится главнейшим фактором роста национального самосознания, постепенного освобождения от колониальной зависимости и реализации государствообразующих национальных проектов.

\section{Библиографический список}

Adams A. Introduction to: Imperial Russia after 1861. Problems in European Civilization. Boston, 1965.

Allworth E. Changing Intellectual and Literary Community // Central Asia: A Century of Russian Rule/E. Allworth (ed.). N. Y.; L.: Columbia Univ. Press, 1967. P. 349-396 https://doi.org/10.1215/9780822396246-013.

Brouer D. Training the Nihilists. Education and Radicalism in Tsarist Russia. L.; N.Y., 1975. DOI: https:// doi.org/10.1086/ahr/82.1.150-a.

Confino M. On Intellectuals and Intellectual Traditions in Eighteenth and Nineteenth Century Russia // Daedalus, 1972. Vol. 101. № 2.

Dukes P.L. October and World. Perspectives on the Russian Revolution. L.; Basingstoke, 1979.

Grant Nigel Soviet Education. Harmondsworth, 1964. Hans N. Russian Tradition in Education. L., 1963.

Johnson William H.E. Russia's Educational Heritage. N.Y., 1969.

Kandel I. Comparative Education. N.Y., 1973.

Kreindler I. T. Educational Policies towards the Eastern Nationalities in Tsarist Russia: a Study of Il'minskii's System. N.Y., 1969.

Lipset H. Education of Moslems in Tsarist and Soviet Russia // Comparative Education Review. 1968. October.

Malia M. The Intellectuals: Adversary or Clerisy? // Daedalus. 1972. V. 101. № 2.

Malia M. Adulthood Refracted: Russia and Leo Tolstoy // Daedalus. 1976. Vol. 105. №.2. P. 173.

Olcott M.B. The Kazakhs. $2^{\text {nd }}$ ed. Stanford: Hoover Institution Press, 1995. 388 p.

Olcott M.B. The politics of language reform in Kazakhstan // Sociolinguistic perspectives on Soviet national languages: Their past, present and future / ed. by J.T. Kreindler. Berlin; N.Y.: Mouton de Gruyter, 1985. P. 183-204.
Seton-Watson H. The Russian Empire. 1807-1917. Oxford, 1967.

Wortman R. «Integrity» (Tselost) of the state in Imperial Russian Representation // Ab Imperio. 2011. № 2. Р. 20-45.

Абай. Книга Слов. Алматы: Ел, 1993. 269 с.

Адельбаева Н.А. Исторический опыт становления и развития школьного образования в Казахстане в XIX - начале XX веков: автореф. дис. ... д-ра ист. наук. Уральск, 2010.

Айтмухамбетов А.А. Народное образование и формирование казахской интеллигенции СевероЗападного Казахстана во второй половине XIX - начале XX века: автореф. дис. ... канд. ист. наук. Омск, 2000.

Буктугурова Р.С. Вклад российской интеллигенции в развитие образования среди казахского населения Степного края в начале XX века // Вестник Тюменского гос. ун-та. 2006. № 4. С. 29-37.

Гуревич Л.Я. Интеллигенция Казахстана и политика тоталитарного государства в сфере науки и высшего образования (1946-1985 гг.): автореф. дис. ... Д-ра ист. наук. Алматы, 1993. 45 с.

Джунджузов С.В., Любичанковский С.В. Миссионерская деятельность Никодима Ленкеевича в Калмыцком ханстве (1725-1734 годы) // Новый исторический вестник. 2017. № 3. С. 172-191.

Джунджузов С.В., Любичанковский С.В. Калмыки на Южном Урале в XVIII - начале XX века: проблемы ассимиляции, аккультурации и сохранения этнической идентичности // Bylye Gody. 2017. Vol. 46. Is. 4. P. 11941206.

Дмитриев В.В., Любичанковский С.В. Южные окраины Российской империи и проблема колониализма (на материалах внутренней политики России по отношению к крымским татарам в конце XVIII - начале XX века) // Bylye Gody. 2017. Vol. 45. Is. 3. P. 1010-1024. DOI: https://doi.org/10.13187/ bg.2017.3.1010.

Левшин А.И. Описание киргиз-казачьих или киргизкайсацких орд и степей. Алматы: Санат, 1996. 656 с.

Любичанковский С.В. Политика аккультурации в условиях разрушения империи: казус волостного земства // Вестник Томского государственного университета. История. 2017. № 50. C. 31-37. DOI: https:// doi.org/10.17223/19988613/50/4.

Очерки по истории Башкирской АССР / под ред. А.П. Смирнова. Уфа, 1956. 300 с.

Хостлер Ч. Тюркизм и советы. Тюрки мира и их политические цели / пер. с англ. Г.М. Мендикуловой / сост. Б.М. Сужиков. Алматы: Санат, 2006. Т. IX. 288 с.

\section{References}

Adams A. Introduction to: Imperial Russia after 1861. Problems in European Civilization. Boston, 1965 [in English].

Allworth E. Changing Intellectual and Literary Community. In: Central Asia: A Century of Russian Rule. E. Allworth (ed.). N. Y.; L.: Columbia Univ. Press, 1967, pp. 349-396 [in English].

Brouer D. Training the Nihilists. Education and Radicalism in Tsarist Russia. London; New York, 1975. DOI: https://doi.org/10.1086/ahr/82.1.150-a [in English]. 
Confino M. On Intellectuals and Intellectual Traditions in Eighteenth and Nineteenth Century Russia. Daedalus, 1972, Vol. 101, No. 2 [in English].

Dukes P. L. October and World. Perspectives on the Russian Revolution. London and Basingstoke, 1979 [in English].

Grant Nigel Soviet Education. Harmondsworth, 1964 [in English].

Hans N. Russian Tradition in Education. London, 1963 [in English].

Johnson William H.E. Russia's Educational Heritage. N. Y., 1969 [in English].

Kandel I. Comparative Education. N. Y., 1973 [in English].

Kreindler I. T. Educational Policies towards the Eastern Nationalities in Tsarist Russia: a Study of Il'minskii's System. N. Y., 1969 [in English].

Lipset H. Education of Moslems in Tsarist and Soviet Russia. Comparative Education Review. 1968. October [in English].

Malia M. The Intellectuals: Adversary or Clerisy? Daedalus, 1972, Vol. 101, no. 2 [in English].

Malia M. Adulthood Refracted: Russia and Leo Tolstoy. Daedalus, 1976, Vol. 105, no. 2, p. 173 [in English].

Olcott M.B. The Kazakhs. $2^{\text {nd }}$ ed. Stanford: Hoover Institution Press, 1995. 388 p. [in English].

Olcott M.B. The politics of language reform in Kazakhstan. In: Sociolinguistic perspectives on Soviet national languages: Their past, present and future. Ed. by J.T. Kreindler. Berlin; N.Y.: Mouton de Gruyter, 1985, pp. 183-204 [in English].

Seton-Watson H. The Russian Empire. 1807-1917. Oxford, 1967 [in English].

Wortman R. "Integrity» (Tselost) of the state in Imperial Russian Representation. $A b$ Imperio, 2011, no. 2, pp. 20-45 [in English].

Abay. Kniga Slov [Book of Words]. Almaty: El, 1993, 269 p. [in Russan].

Adelbaeva N.A. Istoricheskiy opyt stanovleniya $i$ razvitiya shkol'nogo obrazovaniya $v$ Kazakhstane $v$ XIX nachale $X X$ vekov: avtoref. dis. ... d-ra ist. nauk [Historical experience of formation and development of school education in Kazakhstan in the XIX - early XX centuries: author's abstract of Doctor of Historical Sciences]. Ural'sk, 2010 [in Russan].

Aitmukhambetov A.A. Narodnoye obrazovaniye $i$ formirovaniye kazakhskoy intelligentsii Severo-Zapadnogo Kazakhstana vo vtoroy polovine $X I X$ - nachale $X X$ veka: avtoref. dis. ... kand. ist. nauk [Public education and the formation of Kazakh intelligentsia of North-West Kazakhstan in the second half of the XIX - beginning of the XX century: author's abstract of Candidate's of Historical Sciences]. Omsk, 2000 [in Russan].

Buktugurova R.S. Vklad rossiyskoy intelligentsii $v$ razvitiye obrazovaniya sredi kazakhskogo naseleniya
Stepnogo kraya $v$ nachale $X X$ veka [The contribution of Russian intelligentsia to the development of education among the Kazakh population of the Steppe Krai at the beginning of the $20^{\text {th }}$ century]. Vestnik Tyumenskogo gos. un-ta [UT Research Journal], 2006, no. 4, pp. 29-37 [in Russan].

Gurevich L.Ya. Intelligentsiya Kazakhstana i politika totalitarnogo gosudarstva $v$ sfere nauki $i$ vysshego obrazovaniya (1946-1985 gg.): avtoref. dis. ... d-ra ist. nauk [The intelligentsia of Kazakhstan and the policy of totalitarian state in the sphere of science and higher education (1946-1985): author's abstract of Doctor of Historical Sciences thesis]. Almaty, 1993, 45 p. [in Russan].

Dzhundzhuzov S.V., Lyubichankovskii S.V. Missionerskaya deyatel'nost' Nikodima Lenkeyevicha $v$ Kalmytskom khanstve (1725-1734 gody) [Missionary activities of Nikodim Lenkeevich in the Kalmyk Khanate (1723-1734)]. Novyy istoricheskiy vestnik [The New Historical Bulletin], 2017, no. 3, pp. 172-191 [in Russan].

Dzhundzhuzov S.V., Lyubichankovskiy S.V. Kalmyki na Yuzhnom Urale $v$ XVIII - nachale XX veka: problemy assimilyatsii, akkul'turatsii $i$ sokhraneniya etnicheskoy identichnosti [Kalmyks of Southern Ural in the XVIII early XX century: problems of assimilation, acculturation and preservation of ethnic identity]. Bylye Gody, 2017, Vol. 46, Is. 4, pp. 1194-1206 [in Russan].

Dmitriev V.V., Lyubichankovskiy S.V. The Southern Periphery of the Russian Empire and a Problem of Colonialism (on materials of National Policy of Russia in Relation to the Crimean Tatars at the end of XVIII - the beginning of the 20th century). Bylye Gody, 2017, Vol. 45, Is. 3, pp. 1010-1024 [in Russan]. Available at: https://doi.org/ 10.13187/bg.2017.3.1010.

Levshin A.I. Opisaniye kirgiz-kazach'ikh ili kirgizkaysatskikh ord i stepey [Description of Kirghiz-Cossack or Kirghiz-Kaisak hordes and steppes]. Almaty: Sanat, 1996, 656 p. [in Russan].

Lyubichankovskii S.V. Politika akkul'turatsii v usloviyakh razrusheniya imperii: kazus volostnogo zemstva [The policy of acculturation in the conditions of destruction of the empire: the incident of volost zemstvo]. Vestnik Tomskogo gosudarstvennogo universiteta. Istoriya [Tomsk State University Journal of History], 2017, no. 50, pp. 31-37 [in Russan]. Available at: https://doi.org/10.17223/ 19988613/50/4.

Ocherki po istorii Bashkirskoy ASSR. Pod red. A.P. Smirnova [Essays on the history of the Bashkir ASSR. A.P. Smirnov (Ed.)]. Ufa, 1956, 300 p. [in Russan].

Khostler Ch. Tyurkizm i sovety. Tyurki mira i ikh politicheskiye tseli. Per. s angl. G.M. Mendikulovoy. Sost. B.M. Suzhikov [Turkism and Soviets. Torks of the world and their political goals. Translation from English by G.M. Mendikulova. Complier B.M. Suzhikov]. Almaty: Sanat, 2006, Vol. IX, 288 p. [in Russan]. 